\title{
Acute Effects of Alcohol on Cognitive Function and Central Nervous System Assessed by Auditory Event-Related Potentials
}

\author{
Katsuyuki Murata, Shunichi Araki, Takeshi Tanigawa and Eiichi Uchida \\ Department of Public Health, Faculty of Medicine, University of Tokyo, Tokyo
}

\section{Introduction}

Alcohols are widely used as cleaning agents, thinners and for drinking. They are also known to be potent central nervous system depressants and irritants ${ }^{1 \sim 3)}$; for that reason, it mignt be difficult to distinguish the influence on the central nervous system function of alcohol from that of other chemical agents, in particular, among solvent-workers. International review bodies have recommended that increased research be directed toward objective evaluation of central nervous system dysfunctions in persons exposed to organic solvents including alcohols ${ }^{4,5)}$.

The effects of alcohol on latencies of cerebral evoked potentials (EP) originating from the peripheral level of the sensory system remain less clear, although EP amplitudes tend to be depressed ${ }^{6,7)}$. Jensen and Krogh observed a significant prolongation in the P200 latency of visual evoked potentials (VEP) after alcohol intake while the N75, P100 and N145 latencies of VEP did not change ${ }^{8}$; in addition, a significant dose-response relationship between ethanol dose and the P300 component of the event-related potential (ERP) has been reported by some study groups ${ }^{9 \sim 12}$. On the other hand, Skalka et al failed to find significant changes in latencies of the VEP after alcohol ingestion ${ }^{13)}$. Apart from electrophysiological studies, Matsunaga and Mukasa reported that alcohol affected neuropsychological functions such as memory and attention ${ }^{14}$. On the basis of these findings, the EPs with a long latency reflecting higher nervous system functions would be expected to be more sensitive for detection of acute effects of alcohol than those with a relatively short latency.

The EP or ERP technique offers a profitable approach for assessing the level of brain functioning as it permits the concurrent investigation of electrophysiology and cognition. In particular, ERPs can be obtained in conjunction with behavior, or even when no behavioral response is required; they can be recorded for both attended and unattended stimuli ${ }^{15)}$. Thus, the ERP method is considered to be a very sensitive index of the functional integrity of the brain. In the present study, six latencies of the auditory ERP were determined in healthy volunteers to clarify which sites of the central nervous system are influenced by acute administration of alcohol at an early stage.

\section{Materials and Methods}

\section{Subjects}

The subjects consisted of 13 healthy male medical students, aged 20 to 26 (mean 23) years; they consented readily to become volunteers for this study. All these subjects had a history of alcohol-induced facial flushing. They drank alcohol equivalent to 0-450 (mean 100) $\mathrm{ml}$ of $100 \%$ ethanol per week. They were not occupationally exposed to neurotoxic substances such as lead or organic solvents, and had never suffered from neurologic, psychiatric or endocrinological disorders. None of them took drugs, alcohol, cigarettes or other beverages containing caffeine in the afternoon of the examination day .

\section{Study design}

ERP testing was conducted by ingesting $200 \mathrm{ml}$ of Japanese spirits (containing $25 \%$ ethanol) at 4:50-5:00 p.m.; latencies were measured in the same subject at 4:30-4:45 p.m., at 6:00-6:15 p.m. and at 7:00-7:15 p.m. (i.e., before and 1-hr and 2-hr after ethanol ingestion), for a total of three times on the same day. In addition, the ERP testing was done again in the same manner by ingesting 
$200 \mathrm{ml}$ of water on another day for reference to circadian rhythm within the same time period, 4:30-7:00 p.m.

\section{Electrophysiological study}

The auditory ERP was measured by the use of a Medelec MS-92 two channel electromyograph, Medelec ST-10 stimulator and Apple IIe microcomputer in an electrically shielded room. Measurement of the ERP was conducted using a method with the target-selection (i.e. odd-ball) paradigm ${ }^{16,17) .}$ The subject was presented with a random sequence of two distinguishable stimuli; 80 percent of 300 tone bursts of $20 \mathrm{msec}$ duration (rise/fall time, $6 \mathrm{msec}$ ) had a frequency of $1000 \mathrm{~Hz}$ (non-target tone stimuli) and 20 percent had a frequency of $2000 \mathrm{~Hz}$ (target tone stimuli). These stimuli were delivered binaurally via earphones at an intensity of $90 \mathrm{~dB}$ SPL and a rate of 1 tone burst every $2 \mathrm{sec}$. The subject was instructed to count only the target tone mentally. In all cases, the reported total of the target stimuli was correct within 3 stimuli of the actual total presented. Cerebral responses to the two stimuli were recorded at the vertex $(\mathrm{Cz})$ of a 10-20 system and the linked mastoids, and averaged separately (bandpass, 2-100 Hz); then the negative (N100) - positive (P165)-negative (N200) -positive (P300) complex elicited by the target tone and the negative (N100) -positive (P200) complex by the non-target tone were recorded as shown in Fig. 1 . The daily variations (coefficients of variation) in these latencies in a 32 -year-old male subject for 14 days were between $3.2 \%$ and $5.8 \%$.

The ERP components are considered to be as follows ${ }^{15,16)}$ : among components elicited by the target tone, the N100 is enhanced when attention is directed to the sensory channel in which the stimulus occurs. The P165 and N200 are associated with processes that underlie signal identification and response selection. The P300 component is elicited only in circumstances where the subject is required to distinguish one stimulus (target tone) from a group of other stimuli (non-target tone). The P300 latency corresponds to the evaluation time of target stimuli; when the task is difficult, the latency becomes longer. Thus, P300 seems to reflect cognitive function in humans; the functional significance of P300 and other ERP measures is generally inferred from the behavioral data since the physiological substrate of "cognitive" potentials is unknown. On the other hand, the response to the non-target tone consists of a series of waves (i.e. N100 and P200) that relate to an auditory stimulus.

\section{Statistical Analysis}

The Bonferroni multiple comparison method was used to determine the significance levels of repeated measurements in latencies of the ERP on the same day, and of matched differences between tests conducted at the same time on two different days ${ }^{18)}$. The relationships between the change in each latency and dose of ethanol per body weight were tested by Pearson's product moment correlation coefficient. All analyses were performed using the Statistical Packages for the Biosciences (SPBS, Uni-Science Co.).

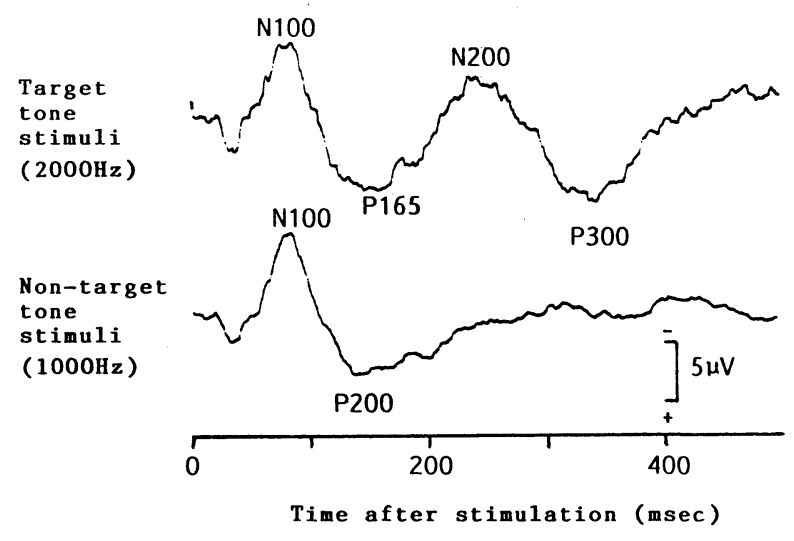

Fig. 1 Waveforms of auditory event-related potentials recorded from the vertex following stimulation of ears by target and non-target tones 


\section{Results}

Table 1 shows ERP latencies before and after ingestion of alcohol and water in 13 male subjects. The latency of P300 elicited by the target tone at 1-hr and 2-hr after alcohol ingestion was significantly longer than that prior to alcohol ingestion, and than the latency measured at the same time on another day when water was administered to the subjects. The N200 latency at 2-hr after alcohol ingestion was also significantly prolonged as compared with that before drinking alcohol. The change in P300 latency observed between before and 2 -hr af ter alcohol ingestion was significantly correlated with the dose of ethanol per body weight in the 13 subjects (Fig. 2), while no change in other latencies was correlated $(\mathrm{p}>0.05)$.

\section{Discussion}

The major results in this study were that P300 latency, as well as N200 latency, were significantly prolonged in subjects with alcohol-induced facial flushing after ethanol ingestion of $0.54-0.74 \mathrm{~g} / \mathrm{kg}$ body weight (BW); the change in P300 latency was significantly correlated with ethanol dose per BW. Therefore, it is suggested that P300 latency is the most sensitive indicator for assessing acute ethanol effects among ERP components with latencies between 100 and $500 \mathrm{msec}$.

Maximally prolonged latencies of P300 and N200 were found at 2-hr after drinking stopped in the present study; while, blood ethanol concentration and the change in heart rate variability have been reported to reach peaks at $30-60 \mathrm{~min}^{8,19}$ ) and at 30-90 $\mathrm{min}^{20}$ ) after intake, respectively. The effect of ethanol on P300 latency related to cognition of higher nervous functions, agrees with the results of other investigations ${ }^{8,10 \sim 12)}$. Acute ethanol intoxication also causes impairment in storage of extremely

Table 1 Latencies of auditory event-related potentials (mean $\pm \mathrm{SD}$, msec) before and $1-\mathrm{hr}$ and 2 - $\mathrm{hr}$ after alcohol or water ingestion in 13 male subjects

\begin{tabular}{|c|c|c|c|}
\hline & Before & $1-\mathrm{hr}$ & $2-\mathrm{hr}$ \\
\hline \multicolumn{4}{|c|}{ Alcohol ingestion } \\
\hline \multicolumn{4}{|c|}{ Target tone: } \\
\hline N100 & $86 \pm 8$ & $88 \pm 6$ & $92 \pm 10$ \\
\hline P165 & $162 \pm 16$ & $166 \pm 15$ & $158 \pm 18$ \\
\hline $\mathrm{N} 200$ & $220 \pm 16^{\mathrm{a}}$ & $231 \pm 25$ & $237 \pm 30^{\mathrm{a}}$ \\
\hline P300 & $317 \pm 22^{c, d}$ & $337 \pm 26 \stackrel{\mathrm{c}}{-}$ & $339 \pm 30 \stackrel{d}{\square}$ \\
\hline \multicolumn{4}{|c|}{ Non-target tone: } \\
\hline N100 & $87 \pm 7$ & $88 \pm 8$ & $89 \pm 8$ \\
\hline P200 & $166 \pm 16$ & $164 \pm 24$ & $168 \pm 22$ \\
\hline \multicolumn{4}{|c|}{ Water ingestion } \\
\hline \multicolumn{4}{|c|}{ Target tone: } \\
\hline N100 & $87 \pm 8$ & $86 \pm 7$ & $85 \pm 7$ \\
\hline P165 & $164 \pm 14$ & $163 \pm 15$ & $159 \pm 8$ \\
\hline N200 & $221 \pm 16$ & $229 \pm 20$ & $224 \pm 20$ \\
\hline P300 & $317 \pm 19$ & $322 \pm 21$ & $320 \pm 24-$ \\
\hline \multicolumn{4}{|c|}{ Non-target tone: } \\
\hline N100 & $86 \pm 6$ & $88 \pm 7$ & $87 \pm 7$ \\
\hline $\mathrm{P} 200$ & $164 \pm 16$ & $163 \pm 17$ & $164 \pm 13$ \\
\hline
\end{tabular}

${ }^{\mathrm{a}, \mathrm{b}} \mathrm{p}<0.05$ and $^{\mathrm{c}, \mathrm{d}, \mathrm{e}} \mathrm{p}<0.01$ (the Bonferroni multiple comparison method was used to determine the significance levels of repeated measurements on the same day, and of matched differences between tests conducted at the same time on two different days). 


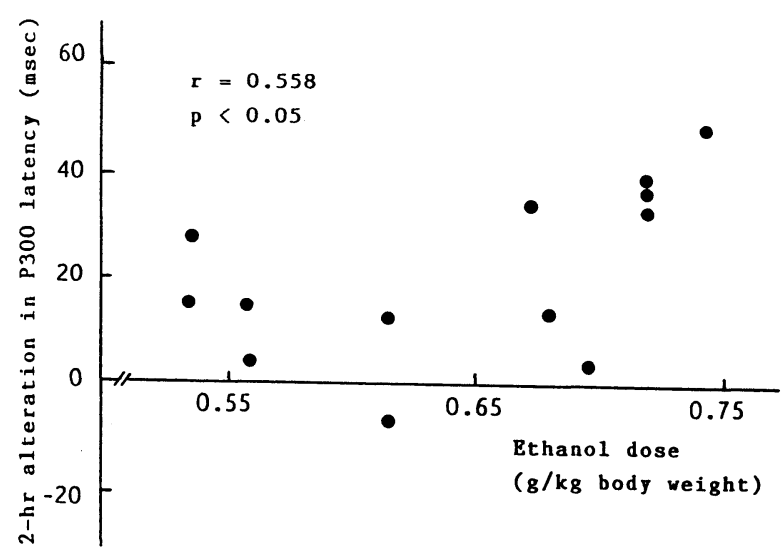

Fig. 2 Relationship between 2-hr alteration in the P300 latency due to alcohol ingestion and dose of ethanol per body weight in 13 male subjects.

$\mathrm{r}$ indicates Pearson's product moment correlation coefficient

short-term memory process in Benton's visual retention test ${ }^{14)}$. On the other hand, Genkina observed that the amplitude of the P300 wave decreased significantly after ingestion of an ethanol dose of 0.82 $\mathrm{g} / \mathrm{kg} \mathrm{BW}$ despite the absence of any significant change in an ethanol concentration of $0.41 \mathrm{~g} / \mathrm{kg} \mathrm{BW}$ by means of the visual ERP ${ }^{9}$. Also, Teo and Ferguson indicated that prolongation of P300 latency with increased ethanol doses was in a dose-dependent manner ${ }^{10}$, as shown in Fig. 2. Thus, it is concluded that ethanol, in proportion to its dose, affects the higher nervous functions, including cognition, at a relatively early stage.

No ethanol-induced prolongation in latencies of less than $200 \mathrm{msec}$ was seen in the current study . A similar finding has been reported by three previous studies ${ }^{8,13,21)}$, in which VEP latencies of more than 180 msec were significantly prolonged but no slowing of latencies below 180 msec could be found (the ethanol doses were between 0.7 and $1.2 \mathrm{~g} / \mathrm{kg} \mathrm{BW}$ ). The VEP latencies, elicited by flash stimuli, of $140 \mathrm{msec}$ and above increased after ethanol administration of $1 \mathrm{~g} / \mathrm{kg} \mathrm{BW}$ level ${ }^{22}$ ). On the other hand, the brainstem auditory evoked potential (BAEP) with a latency of less than only $10 \mathrm{msec}$ is well-known to be resistant to changes in attention or consciousness and to pharmacologic insults ${ }^{23}$; whereas, some "peak" latencies of the BAEP were significantly prolonged after ethanol intake of $1 \mathrm{~g} / \mathrm{kg} \mathrm{BW}$ (the authors did not test the statistical significance of the changes in their "interpeak" latencies) ${ }^{24)}$. In this way, the relatively short-latency EPs appear to be less affected by ethanol; such EPs might also respond to higher doses as it is likely that all brain loci are ultimately affected by ethanol.

Teo and Ferguson, however, found a significant prolongation in the N100, P165, N200 and P300 latencies of ERP after ethanol intake of $0.54 \mathrm{~g} / \mathrm{kg} \mathrm{BW}^{10)}$, which is not consistent with our results in regard to the dose and influenced peaks. Two explanations are possible for this disagreement: (1) When ethanol was administered to the subjects, Teo and Ferguson adulterated it with orange juice and we did so only with water. For that reason, the absorption rate of ethanol in the stomach and small intestine might have been different between these two groups. (2) About 50-60\% of Orientals exhibit ethanol-induced facial flushing, but only a few percent do so among Caucasians ${ }^{25)}$. It has also been reported that flushers are deficient in aldehyde dehydrogenase I, which has a low Km value for acetaldehyde ${ }^{26)}$; nevertheless, the alteration of blood ethanol concentration in flushers was similar to that in non-flushers ${ }^{19)}$. Accordingly, the above discord may be attributable to the difference in race and genetic predisposition between Japanese and Australian subjects.

Cellulotoxic studies do not yet of fer a comprehensive and consistent interpretation of the effects of ethanol on electrophysiological processes in single neurons or integrated circuits. There have been two hypotheses concerning ethanol toxicity: (1) the major effects of ethanol are on synaptic transmission 
and are cumulative in polysynaptic paths ${ }^{3,27)}$ and (2) the mechanism of action probably involves interference with ion transport at the cell membrane rather than at synapses ${ }^{1}$. The VEP latency has been considered to be a sensitive indicator of both long- and short-term exposure such as visual fatigue induced by visual display terminal work ${ }^{28)}$. Thus, latencies of VEP or P300 may be easily affected by changes in the arousal or cognitive function of the cortex due to visual fatigue or ethanol, inasmuch as these latencies have many synaptic circuits in the long pathway between the periphery and cortex . In contrast, latencies of the short-latency somatosensory evoked potentials or BAEP may be resistant to acute effects of ethanol, since they have at most a few synapses. Further study will be required to establish the cellulo-physiological mechanism in alcoholic neurotoxicity .

Finally, long-term brain impairment in chronic alcoholics also has been observed by Ciesielski et $\mathrm{al}^{29}$ ), who suggested that cognitive brain potentials (N200 and P300) were more sensitive indicators of cerebral impairment than psychometric data. Thus, alcohol is considered to be one of the most important confounders for ERP testing. When long-latency EPs, including ERPs, are measured to evaluate subclinical effects of environmental neurotoxins such as organic solvents, particular attention should be paid to not only the degree of the daily drinking habit (i.e., its dose, frequency and duration) but also the interval between the measurement and alcohol intake, together with other confounders (e.g. , age $)^{16)}$, to preserve the comparability of the ERP data between exposed and unexposed groups .

\section{Summary}

To clarify which sites of the central nervous system are influenced by acute administration of alcohol at an early stage, auditory event-related potentials (ERP) using a target-selection paradigm were measured in 13 healthy volunteers. In the recorded waveforms of ERPs, the N100, P165, N200 and P300 latencies for the target tone and the N100 and P200 latencies for the non-target tone were determined in each subject before and 1- and 2-hr after ingestion of $200 \mathrm{ml}$ of alcohol (containing 25\% ethanol) or of $200 \mathrm{ml}$ of water, for a total of six times on two different days. The P300 latency was significantly prolonged at 1 - and 2-hr after alcohol ingestion; and, the N200 latency was significantly prolonged at 2 -hr after alcohol ingestion. The 2-hr alteration in the P300 latency after alcohol ingestion was positively correlated with the ethanol dose per body weight. These data suggest that ethanol, in proportion to its dose, affects cognitive function estimated by the P300 latency earlier than other lower central nervous system functions. Evaluating subclinical effects on central nervous function, using the ERPs, of environmental neurotoxins such as organic solvents, researchers should pay particular attention not only to the degree of the drinking habit but also to the interval between the measurement and alcohol intake.

Requests for reprints should be sent to: Prof. S. Araki, Department of Public Health, Faculty of Medicine, University of Tokyo, 7-3-1 Hongo, Bunkyo-ku, Tokyo 113.

\section{References}

1 ) Ellenhorn, M. J. and Barceloux, D. G.: Medical Toxicology, pp.782-797, Elsevier, New York (1988).

2 ) LaDou, J. : Occupational Medicine, Aplleton \& Lange, Norwalk (1990).

3 ) Rall, T. W.: Hypnotics and sedatives: ethanol, in "Goodman and Gilman's The Pharmacological Basis of Therapeutics, 8th Edn" (eds.: A. G. Gilman, T. W. Rall, A. S. Nies and P. Taylor), pp.1345-1385, Pergamon Press, New York (1990).

4 ) NIOSH.: Organic Solvent Neurotoxicity (Current Intelligence Bulletin 48), U. S. Department of Health and Human Services, Cincinnati (1987).

5 ) Agency for Toxic Substances and Disease Registry: Toxicological Profile for Toluene, U. S. Department of Health and Human Services, Atlanta (1989).

6 ) Porjesz, B. and Begleiter, H.: Human evoked potentials and alcohol, Alcoholism Clin. Exp. Res., 5, 304-317 (1981). 
7 ) Campbell, K. B. and Lowick, B. M.: Ethanol and event-related potentials: the influence of distractor stimuli, Alcohol, 4, 257-263 (1987).

8 ) Jensen, O. L. and Krogh, E.: Visual evoked response and alcohol intoxication, Acta Ophthalmol., 62, 651-657 (1984).

9 ) Genkina, O. A.: Effect of alcohol on evoked electrical activity in healthy man, Hum. Physiol., 10, 189-192 (1984).

10) Teo, R. K. C. and Ferguson, D. A.: The acute effects of ethanol on auditory event-related potentials, Psychopharmacology, 90, 179-184 (1986).

11) Oscar-Berman, M. : Alcohol-related ERP changes in cognition, Alcohol, 4, 289-292 (1987).

12) Rohrbaugh, J. W., Stapleton, J. M., Parasuraman, R., Zubovic, E. A., Frowein, H. W., Varner, J. L., Adinoff, B., Lane, E. A., Eckardt, M. J. and Linnoila, M. : Dose-related effects of ethanol on visual sustained attention and event-related potentials, Alcohol, 4, 293-300 (1987).

13) Skalka, H. W., Helms, H. and Holman, J.: Effects of ethyl alcohol on VECP, Doc. Ophthalmol., 62, 47-51 (1986).

14) Matsunaga, K. and Mukasa, H.: The effect of alcohol on the human memory, Jpn. J. Alcohol Drug Depend. , 21, 64-73 (1986). (in Japanese with English abstract)

15) Picton, T. W. and Stuss, D. T.: The component structure of the human event-related potentials, in "Motivation, Motor and Sensory Processes of the Brain: Electrical Potentials, Behaviour and Clinical Use (Prog. Brain Res. Vol. 54)" (eds. : H. H. Kornhuber and L. Deecke), pp.17-49, Elsevier, Amsterdam (1980).

16) Goodin, D. S. : Event-related (endogenous) potentials, in "Electrodiagnosis in Clinical Neurology, 2nd Edn" (ed.: M. J. Aminoff), pp.575-595, Churchill Livingstone, New York (1986) .

17) Araki, S., Murata, K., Yokoyama, K. and Uchida, E. : Auditory event-related potential (P300) in relation to peripheral nerve conduction in workers exposed to lead, zinc, and copper: effects of lead on cognitive function and central nervous system, Am. J. Ind. Med., 21, 539-547 (1992) .

18) Morrison, D. F.: Multivariate Statistical Methods, pp.128-169, McGraw-Hill, New York (1976).

19) Tanaka, T. and Mukasa, H.: The individual differences in responses after alcohol ingestion, Jpn. J. Alcohol Drug Depend. , 20, 375-387 (1985). (in Japanese with English abstract)

20) Weise, F., Krell, D. and Brinkhoff, N.: Acute alcohol ingestion reduces heart rate variability, Drug Alcohol Depend. , 17, 89-91 (1986).

21) Erwin, C. W . and Linnoila, M.: Effect of ethyl alcohol on visual evoked potentials, Alcoholism Clin. Exp. Res. , 5, 49-55 (1981).

22) Zuzewicz, W.: Ethyl alcohol effect on the visual evoked potential, Acta Physiol. Pol., 32, 93-98 (1981).

23) Stockard, J. J., Stockard, J. E. and Sharbrough, F. W.: Brainstem auditory evoked potentials in neurology: methodology, interpretation, and clinical application, in "Electrodiagnosis in Clinical Neurology, 2nd Edn” (ed.: M. J. Aminoff), pp.467-503, Churchill Livingstone, New York (1986).

24) Church, M. W. and Williams, H. L.: Dose- and time-dependent effects of ethanol on brain stem auditory evoked responses in young adult males, Electroencephalogr. Clin. Neurophysiol. , 54, 161-174 (1982).

25) Kubouchi, H., Suwaki, H. and Ohara, H.: The relationship of the intensity of alcohol-induced flushing to drinking patterns in Japanese students, Jpn. J. Alcohol Drug Depend., 22, 352-365 (1987). (in Japanese with English abstract)

26) Harada, S., Agarwal, D. P., Goedde, H. W., Takagi, S. and Ishikawa, B.: Possible protective role against alcoholism for aldehyde dehydrogenase isozyme deficiency in Japan, Lancet, II, 827 (1982).

27) Kalant, H. and Woo, N. : Electrophysiological effects of ethanol on the nervous system, Pharmacol. Ther., 14, 431-457 (1981).

28) Murata, K., Araki, S., Kawakami, N., Saito, Y. and Hino, E.: Central nervous system effects and visual fatigue in VDT workers, Int. Arch. Occup. Environ. Health, 63, 109-113 (1991). 
29) Ciesielski, K. T., Madden, J. S., Bligh, J. G. and Schopflocher, D. : Long-term brain impairment in chronic alcoholics: N2-P3 cognitive potentials in a template-matching memory task, Alcohol Alcoholism, 20, 403-408 (1985).

(Received May 11, 1992/Accepted September 3, 1992)

\title{
認知および中枢神経機能に及ぼす急性アルコール摂取の影響 \\ 一聴性事象関連電位を用いた検討一
}

\author{
村田 勝 敬, 荒記 俊一, 谷川 武, \\ 内田栄一
}

東京大学医学部公衆衛生学教室

急性アルコール摂取により中枢神経のぞの部位が早期に影響されるかを明らかにするため，健常対象者13名の目標一 選択課題を用いた聴性事象関連電位を測定した。事象関連電位の記録波形のらち, 目標刺激音によって誘発されるN100, P165，N200，P300潜時および非目標刺激音によるN100，P200潜時が，200mlのアルコール(エタノールを25\%含有)の摂 取前, 摂取後 1 および 2 時間に測定された。さらに, これらの潜時は $200 \mathrm{ml}$ の水摄取前後でも同様に測定された(各被 検者とも 2 日間計 6 回測定)。

主な結果は以下の通りであった。

1. P300潜時は拎酒後 1 および 2 時間で有意に延長した。N200潜時も领酒後 2 時間で有意に延長した。その他の潜時 には有意な変化が見られなかった。

2. 领酒後 2 時間のP300潜時の変化は体重当りのエタノール量と有意な正の相関があった。

3 . 水黍取による事象関連電位潜時の変化は認められなかった。

P300潜時は認知機能を反映すると考兄られている。従って, エタノールは, その摂取量に比例して, 下位中枢神経 系機能よりも早期に高次中枢神経 (認知) 機能に影響を及ぼすことが示唆された。有機溶剂のような環境中の神経毒性物 質の中枢神経系機能に及洔す影響を評価する場合，领酒習慣の程度だけでなく測定前の飲酒時刻に対しても特別の注意 が払われるべきである。

Key words: Event-related potentials (P300), Acute effects of ethanol, Central nervous system , Cognitive function, Confounder, Humans 事象関連電位 $(\mathrm{P} 300)$, 急性アルコール影響, 中枢神経系, 認知機能, 交絡因子, 七ト 